\title{
Progressing a Sustainable-world: A Case Study of the South Australian Government
}

\author{
Don Clifton, MBA (Advanced), MABP, BA, GAICD \\ $\mathrm{PhD}$ Candidate, University of South Australia \\ City West Campus, North Terrace, Adelaide, South Australia \\ Tel: 61-8-8463-0850 E-mail: doncmail@bigpond.net.au
}

\begin{abstract}
This paper discusses a component of a current research project that is concerned with what it means for humanity to live sustainably, that is, for there to be a sustainable-world, and how this might be achieved. Specifically, the paper presents the findings of a case study of the South Australian Government's (SAG's) sustainable-world approach. Of the two main sustainable-world approaches evident in the literature - the Reformist-approach and the Transformational-approach - the SAG's policies, plans, and goals are shown to be, for the most, consistent with Reformism. Two main exceptions are noted, namely the SAG's population and defence industry strategies, both of which are shown to be challenging to reconcile with either the Reformist or Transformational approaches. The findings also show that, from an Ecological-Footprint perspective, the South Australian community is not living sustainably within the global context. Despite the SAG's claims of sustainability leadership, its Ecological-Footprint goal will, even if achieved, see the South Australian community continue this unsustainable way of life.
\end{abstract}

Keywords: Sustainable-world, Ecological footprint analysis, Socio-ecological resilience, South Australia, South Australian Government

\section{Introduction}

This paper discusses a component of a current research project (the Project) that is concerned with what it means for humanity to live sustainably, that is, for there to be a sustainable-world, and how this might be achieved (for an overview of the entire Project, see Clifton (2010c)). The Project comprises two main components.

First is a literature review and analysis to answer Project Question 1: what does it mean for there to be a sustainable-world?, for which there are five sub-questions namely: (a) what different sustainable-world approaches are evident in the literature?, (b) which of these is the current dominant approach?, (c) what human activities are inconsistent with these approaches?, (d) what best represents the current dominant human behaviour in reference to these approaches?, and (e) is the current dominant approach a viable pathway for humanity to progress a sustainable-world outcome?

The second part of the Project reviews the sustainable-world approach of the South Australian Government (SAG). The purpose of this case study is: (a) to identify, in a practical setting, areas of confirmation or discrepancy with the Q1 findings, and (b) to consider initiatives at the local level in terms of a global sustainable-world goal. This gives rise to a two-part SAG case study question: Q2(a) - what sustainable-world approach is the SAG pursuing?, and Q2(b) - in the light of the Q1 findings, what implications arise from the SAG's approach in respect to its contribution to, or detraction from, a global sustainable-world goal? The SAG was chosen for this Project component for two main reasons. First, governments are seen as key social actors in contributing to current sustainable-world problems and in driving needed change (Alcott, 2008; Gould, Pellow, \& Schnaiberg, 2008; Speth, 2008; WCED, 1987). Second, the SAG is an instructive example as: (a) it is democratically elected and, in this sense, has a purpose to act in the interests of its constituents (Parkin, 2006), (b) it holds itself out as a sustainability leader (SAG, 2007v, 2008e, 2008f, 2008j), and (c) it has broad constitutional powers to pass legislation and pursue policy initiatives within South Australia's borders (SA, 2003a).

This paper proceeds as follows. Section 2 summarises the key findings from the literature review and analysis that was conducted to answer Project Q1 and its sub-questions, as relevant to this paper. In section 3, the methodology used to conduct the research in relation to Q2(a) and Q2(b) is reviewed with the findings presented in section 4. Section 5 discusses the implications of the findings, key contributions to knowledge, limitations, and areas for further research, with Section 6 presenting some concluding comments. 


\section{Project $Q 1$ issues and their implications for the $S A G$ case study}

This section considers what it means for there to be a sustainable-world and overviews two main approaches evident in the literature, namely the Reformist-approach and the Transformational-approach. In section 2.2, the Reformist-approach, which is consistent with mainstream sustainable-development, is identified as the dominate sustainable-world approach in political and business circles. Section 2.3 then discusses the application of Ecological Footprint Analysis (Footprint-Analysis) in conjunction with I=PAT, and the concept of socio-ecological-resilience, in assessing the merits of Reformism as a credible sustainable-world approach. This is followed in section 2.4 by a review of how Footprint-Analysis can be applied in assessing local action (i.e., the $\mathrm{SAG})$ in terms of a global sustainable-world objective.

\subsection{Project Q1(a): A sustainable-world}

Despite its broad uptake, the sustainable-world concept remains pluralistic and contested in meaning (Manderson, 2006; Porritt, 2005). Dobson (1996) recommends a typology approach to present the meaning of such complex concepts, and the Project followed Dobson's advice with representations of a sustainable-world presented as a sustainable-world typology. (For a full version of this typology, see Clifton (2010b)). The sustainable-world typology is built around a set of dimensions identified from the literature - shown as Figure 1 - that collectively give meaning to the sustainable-world concept.

\section{<insert Figure 1 here>}

The literature review revealed two main sustainable-world approaches as to how the dimensions in Figure 1 are collectively constructed, namely the Reformist-approach and the Transformational-approach. For both approaches, the primary sustainable-world goal can be summarised as 'the flourishing of life, incorporating human and ecological wellbeing, maintained over an indefinite time frame, with this wellbeing grounded in principles of intra-generational and inter-generational justice'. Beyond this general claim, the two approaches differ substantially.

Reformism focuses the achievement of a sustainable-world on reforming the current dominant socio-economic system through changes at the margin to make this system more environmentally responsible and socially just (green-and-just) (Cato, 2009; Fox, 2003; Madore, 2006; Williams \& Millington, 2004). This approach is characterised by: (a) an anthropocentric bias, (b) meeting human needs through a focus on the consumption of goods and services produced and consumed in green-and-just ways, and delivered principally through capitalist markets, (c) human population policies focused on stabilising population numbers, (d) maintaining the current process of human development built around continued economic growth and technology advance, but done in green-and-just ways, (e) a commitment to continued economic growth to overcome problems of poverty and to promote human wellbeing, (f) continuation of the globalisation and free-trade agenda to underpin these economic and social goals, and (g) technology advance to drive growth, improve human wellbeing, and address any negative ecological impacts harmful to human wellbeing.

The Transformational-approach claims that progressing to, and the maintaining of, a sustainable-world requires fundamental socio-economic system change (Cato, 2009; Naess, 2003; Williams \& Millington, 2004). This approach is characterised by: (a) an ecocentric bias, (b) meeting human needs through consumptive sufficiency and a focus on non-material satisfiers, (c) a long-term reduction in human population numbers and an increase in the populations of most non-human species, (d) continued consumptive growth as unsustainable, (e) poverty as best resolved through resource reallocation not more global resource-through-put growth, with a key role for the politically and economically powerful, especially the industrialised North, to cease the exploitation of resources from the politically and economically weak, and (f) quantitative constraints placed on natural resource use and waste discharge into the Earth's ecosystems, such that they remain well within ecosystem limits.

These Q1(a) findings form the framework on which the analysis of the SAG's policies, plans, and goals is based in order to answer Q2(a) - what sustainable-world approach is the SAG pursuing?

\subsection{Project Q1(b): Current dominant sustainable-world approach}

The literature shows Reformism as the current dominant sustainable-world approach (Gould \& Lewis, 2009; Nurse, 2006). This dominance is based on Reformism being embraced, in the form of mainstream sustainable-development, by the key centres of social power, namely the political and business domains (Castro, 2004; Dauvergne, 2008; Robinson, 2004).

Based on the dominance of Reformism in the political domain, the expectation is that the SAG's sustainable-world approach would, for the most, be consistent with Reformism and framed within the mainstream sustainable-development narrative. 


\subsection{Project Q1(e): Reformism as a credible sustainable-world approach}

For the Project, two concepts were applied in assessing Reformism's merits as a viable sustainable-world approach, namely: (a) Footprint-Analysis in conjunction with I=PAT, and (b) socio-ecological-resilience. Although not the only concepts that could have been used for exploring this merits-of-Reformism issue, they are particularly instructive in that, as discussed below, both are concerned with necessary conditions for there to be a sustainable-world.

\subsubsection{Footprint-Analysis and I=PAT}

A detailed review of the Footprint-Analysis and I=PAT critique of Reformism conducted as part of the Project is presented in Clifton (2010d), however, in brief, the key points from this review are as follows.

Footprint-Analysis (Footprint Network, 2010; Kitzes, 2007) is a process of: (a) calculating an Ecological-Footprint, expressed in units of global hectares per capita (ghpc), to show the rate at which a unit of analysis (say, a city, nation, or all of humanity) is using the Earth's renewable natural resources, (b) calculating available Biocapacity, that is, the regenerative and waste-sink capacity of the Earth's renewable natural resources, also as ghpc, and (c) comparing the two measures to show either an ecological-deficit or ecological-credit. As such, Footprint-Analysis presents a measure of a necessary, although not sufficient, condition for humanity to live sustainably, that being to live within the Earth's Biocapacity limits (Footprint Network, 2006; Giljum et al., 2007).

Based on the most recent Footprint-Analysis data (see Figure 2), humanity is, at a global level, not living sustainably in Footprint-Analysis terms. The current global-level Ecological-Footprint of 2.6ghpc is running at about $144 \%$ of available Biocapacity of 1.8ghpc (Footprint Network, 2009). Further, if allowance is made in the standard Footprint-Analysis data for Biocapacity that is not available for human use (i.e, to allow for Biocapacity needed by other species, to maintain ecosystem resilience, and to allow for the conservative nature of the Footprint-Analysis data), the degree of ecological-deficit is substantially higher (Clifton, 2010d).

\section{<insert Figure 2 here>}

The Reformist solution to this problem of ecological-deficit can be considered in terms of I=PAT. I=PAT (Chertow, 2000; Holdren, Daily, \& Ehrlich, 1995; York, Rosa, \& Dietz, 2003) presents human impact on the environment 'I' (or, as used here, Ecological-Footprint), as a function of:

Population,

Affluence; as consumption/production per capita, with GDP per capita often used as a proxy measure, and

Technology; as the environmental impact per unit of consumption/production.

For Reformism, a reduction in total ' $\mathrm{P}$ ' is not under consideration, increasing 'A' through strong global economic growth is central to its agenda, with ' $T$ ' being the key to ensuring 'I' (Ecological-Footprint) is kept within sustainable limits. The Project findings, however, suggest that reliance on 'T' to deliver needed reductions in 'I' to address the current ecological-deficit problem and counter the pressures on 'I' from future growth in both 'P' and ' $\mathrm{A}$ ' is, to say the least, challenging to believe as credible and well beyond any observable experience. Figure 3 summarises the Footprint-Analysis data projected to 2050 illustrating the magnitude of the challenge ' $\mathrm{T}$ ' strategies confront based on pursuing the Reformist agenda. Further, some of the ' $\mathrm{T}$ ' strategies that are advocated as key solutions to the ecological-deficit problem, in particular optimising the productivity of the Earth's renewable natural resources, and pursuing efficiency gains in the production process, can undermine ecosystem resilience (Meadows, Randers, \& Meadows, 2004; Walker \& Salt, 2006) and drive further production and consumption such that it negates some or all of the resource reduction gains that were otherwise expected (Gould et al., 2008; Polimeni, Mayumi, Giampietro, \& Alcott, 2009; Princen, 2005). In short, the review of Reformism conducted as part of the Project shows it to be challenging to accept as a viable pathway for humanity to progress to a sustainable-world outcome.

\section{<insert Figure 3 here $>$}

For the SAG case study, two important issues arise from this discussion. The first is that I=PAT can present a simple model for representing the SAG's sustainable-world approach. If the SAG were pursuing the Reformist agenda, we would expect to see strategies focused on keeping Population relatively stable, actively increasing Affluence (as GDP), and a strong focus on $\underline{T}$ echnology to offset any negative ecological impacts from 'P+A'. Alternately, if it were pursuing the Transformational agenda, we would expect to see strategies focused on reducing ' $\mathrm{P}$ ', 'A' considered in terms of consumptive sufficiency, and ' $\mathrm{T}$ ' as part of an overall strategy to reduce human ecological impacts as opposed to an area of primary focus (for a detailed I=PAT summation of the 
Reformist and Transformational approaches, see Clifton (2010d)). Such an I=PAT analysis is shown in section 4.3.

The second issue is that if, as expected, the SAG's sustainable-world approach is consistent with Reformism, then the reservations expressed in this section as to the merits of Reformism as a viable pathway to transition society to one that is living sustainably would similarly apply in the SAG setting.

\subsubsection{Socio-ecological-resilience}

Socio-ecological-resilience is an approach to resilience in the complex-adaptive-systems context, and is defined as:

"(1) the amount of disturbance a system can absorb and still remain within the same state or domain of attraction,

(2) the degree to which the system is capable of self-organization (versus lack of organization, or organization forced by external factors), and

(3) the degree to which the system can build and increase the capacity for learning and adaptation" (Folke, 2006, pp. 259-260).

A number of authors (e.g., Handmer \& Dovers, 1996; Holling, 1996; Walker \& Salt, 2006) have noted that this form of resilience is fundamental to there being a sustainable-world. The key point is that, in the sustainable-world context, a system "remain[ing] within the same state or domain of attraction" is concerned with the ability of socio-ecological-systems to continue to meet the primary sustainable-world goal - the flourishing of life, incorporating human and ecological wellbeing, maintained over an indefinite time frame and doing so regardless of what changes might occur to these systems over time. In this respect, the resilience and sustainable-world concepts are inseparable.

A socio-ecological-resilience critique of both the Reformist and Transformational approaches is presented in Clifton (2010a) which, in summary, shows Reformism as lacking consistency with socio-ecological-resilience principles in three main ways namely: (a) it exposes human decision making to greater risks of error that may harm human and ecological wellbeing than is evident for the Transformational-approach, (b) its commitment to maximisation and optimisation strategies - such as strong and continuous consumptive-based economic growth, and optimising natural resource productivity - actively erode socio-ecological system resilience making Reformism, in this respect, inherently self-defeating, and (c) by limiting solutions to progressing a sustainable-world to what is effectively a green-and-just version of the current neo-liberal economic agenda, Reformism acts as a barrier to the uptake of other solutions that may well be needed to see a sustainable-world come about. In all respects, the Transformational-approach is shown as more consistent with socio-ecological-resilience principles.

As for the Footprint-Analysis and I=PAT issues discussed above, if the SAG is pursuing a Reformist sustainable-world approach, then the inconsistencies between Reformism and socio-ecological-resilience principles, and the implications that flow from this, also apply in the SAG setting.

\subsection{Project Q2(b): Assessing the local in terms of the global}

In addition to its application in assessing the merits of Reformism as a viable sustainable-world approach, Footprint-Analysis, by its use of a standardised measure - global hectares per capita (ghpc) - allows for the comparison of data between different units of analysis (Giljum et al., 2007; Kitzes, Peller, Goldfinger, \& Wackernagel, 2007). This sees Footprint-Analysis as a useful tool for assessing the implications of the local - in this case, the SAG setting - within the global context, and hence useful in exploring Project Q2(b).

A detailed review of the application of Footprint-Analysis to assess the extent to which a sub-global region is living sustainably in Footprint-Analysis terms is shown in Clifton (2010e) which, in summary, identifies four key non-mutually exclusive tests for conducting such an assessment namely:

(1) That a region's consumption-based Ecological-Footprint (i.e., Ecological-Footprint based on what the region consumes regardless of where the consumed goods are produced) remains within that region's Biocapacity limits (note: the consumption-based measure is the standard form of the Ecological-Footprint).

(2) That a region's production-based Ecological-Footprint (i.e., Ecological-Footprint based on the production activities occurring within a region's borders) remains within its Biocapacity limits. 
(3) That a region's per capita Biocapacity use remains within the limits of a 'fair-Earth-share', where the fair-Earth-share is equal to total global Biocapacity that can safely be used by humans, divided by the total global population.

(4) One based on the generalisation-principle where a region's renewable natural resource use, and how this region's behaviours might impact on resource use over time, is considered in terms of whether it is generalisable to all of humanity and for a sustainable-world to still come about - if it is not generalisable then the region is not living sustainably.

Of these four, the first two tests are limited in their application to the global sustainable-world context as both focus too heavily on local behaviour without linking it to the broader global context - both for example do not question the fairness of the local Ecological-Footprint measure in a broad social justice context, but merely link it to local available Biocapacity. The third (fair-Earth-share) and fourth (generalisation-principle) tests are, in this respect, the most telling, as they link directly to issues of justice that are central to sustainable-world issues. In section 4.3, these four tests are applied in the SAG setting to consider this local-to-global issue.

\section{Methodology}

For Q2(a), a document-analysis case study of the SAG's sustainable-world approach was conducted, structured on the case study guidelines proposed by Yin (2003). The Project considered only the SAG's policies, plans, and goals, and did not look at the actual performance of the SAG in achieving its stated objectives. For the purposes of the study, the SAG comprised the elected members of the in-power political party during the term of the Project, namely the Labor Party of South Australia under the leadership of Premier Rann, and its supporting public service sector. The case study focused on the period from when this Government first came to power in March 2002, through to 2010.

The SAG facilitated the research by granting the researcher ongoing access to members of SAG departments to provide an orientation to the SAG by way of its departmental and Ministerial structure and the roles these parties play, and to gain direction to documents that might be beneficial to the research. Access to the SAG, and referrals to SAG departments, was arranged through the Chief Executive of the Sustainability and Climate Change Division of the Department of the Premier and Cabinet.

Over 300 documents were sourced and analysed, including documents produced by the SAG and by parties external to it. Summary details are shown as Figure 4. Documents were sourced from: (a) recommendations by people within the SAG (as referred to above), (b) a search of SAG web sites, (c) references in already sourced documents, (d) subscriptions to SAG e-news releases, and (e) the general media (i.e., media items themselves plus references to SAG documents referred to in the media). Document gathering commenced during the early stages of the literature review and analysis in relation to Project Q1, and continued in parallel with Q1 exploration. Data analysis commenced once the basic structure of the sustainable-world typology (referred to in section 2.1) was settled (that is, once the basic descriptions of the different sustainable-world approaches were determined) and continued in parallel with the document sourcing process.

Data analysis was conducted in three ways. First, data was assessed based on the sustainability language evident in SAG documents. Sustainability terminologies identified in the literature review from which the sustainable-world typology was developed, such as 'sustainable-development', 'environmental-sustainability', 'social-sustainability' and so on (see Clifton (2010b)), were entered as nodes in the NVIVO software system. The SAG sustainability terminologies, the meanings given to them, and the context in which they were used, were coded to these nodes. These terminologies were then assessed in terms of the general features of the Reformist and Transformational approaches to consider the consistency or otherwise of the SAG's sustainability language with these two sustainable-world approaches.

Next, the SAG's broader policies, plans, and goals were assessed from a sustainable-world perspective using both theoretical and inductive thematic analysis as outlined by Braun \& Clarke (2006). The dimensions shown in the sustainable-world typology (as per Figure 1) were entered as nodes in NVIVO, with document content coded to these nodes (i.e., theoretical analysis). Content was then classified in terms of either the Reformist or Transformational approaches (i.e., theoretical analysis) or noted as exceptions (i.e., inductive analysis). The document gathering and data analysis process continued in parallel to a point of saturation where no new findings of significance to the Project were materialising.

Finally, the SAG's population, economic growth, and technology strategies were modelled using I=PAT (as per section 2.3.1), with the implications of this modelling considered in Reformist and Transformational terms. 
The collective findings from these three analysis processes were then reviewed from which overall conclusions concerning the SAG's sustainable-world approach were drawn.

\section{<insert Figure 4 here>}

Project Q2(b) was answered in reference to the Q1 findings summarised in section 2. For the Footprint-Analysis and I=PAT critique, the SAG's sustainable-world approach was modelled using I=PAT and the implications of this considered in terms of the general Project findings reported in section 2.3.1. Next, the SAG's sustainable-world approach was assessed in terms of the findings of the socio-ecological-resilience critique of the Reformist and Transformational approaches as discussed in section 2.3.2. Finally, the SAG's Footprint-Analysis goals were analysed based on the four tests shown in section 2.4 to consider the extent to which these goals are consistent with a global sustainable-world objective.

\section{Findings}

\subsection{Sustainability language}

Sustainability language features prominently in SAG documents including strategic planning documents, departmental reports, enacted legislation, media releases, brochures, and web sites. This language includes common terminologies such as 'sustainability', 'sustainable-development', 'environmental/ecological sustainability', 'economic-sustainability' and 'social-sustainability'. In addition, a broad range of specific units of focus are identified as things to be sustained and/or conducted in sustainable ways, including communities, the use of natural resources, economic development/growth, and various industries. A summary of the more common terminologies and sustainability units of focus is shown in Figure 5.

Although sustainability terms are at times used by the SAG in ways that are backed by an explanation of meaning and/or formal definition, more often than not they appear as undefined common language within a general sustainability narrative. Within this array of terminologies, two key concepts are evident that give meaning to the SAG's sustainability narrative and help explain why sustainability is so pervasive within SAG documents, namely: (a) Ecologically Sustainable Development (ESD) and (b) Attaining Sustainability.

\section{<insert Figure 5 here>}

\subsubsection{Ecologically Sustainable Development (ESD)}

The key document that gives meaning to ESD in the Australian political context is the 1992 National Strategy for Ecological Sustainable Development (AG, 1992b), which defines ESD as:

"'using, conserving and enhancing the community's resources so that ecological processes, on which life depends, are maintained, and the total quality of life, now and in the future, can be increased [or], [p]ut more simply, ESD is development which aims to meet the needs of Australians today, while conserving our ecosystems for the benefit of future generations".

This definition is supported by:

(a) An ESD goal of "Development that improves the total quality of life, both now and in the future, in a way that maintains the ecological processes on which life depends".

(b) Three objectives of:

- enhancing individual and community well-being through economic development,

- intra-generational and inter-generational equity, and

- protection of biodiversity and essential ecological processes.

(c) A set of guiding principles for progressing ESD including the need:

- to consider economic, environmental, and social issues,

- to apply the precautionary-principle in decision making,

- to consider environmental issues at the global level,

- for a strong, growing, diversified and internationally competitive economy,

- for cost-effective and flexible policy instruments, and

- for community involvement in decision making.

In 1992, the Australian Commonwealth, State and Territory Governments, and the Local Government Association, signed the Inter-governmental Agreement on the Environment that, amongst other things, includes 
provisions requiring the parties to apply ESD concepts to "inform policy making and program implementation" and to "promote the integration of environmental considerations into Government decision making" (AG, 1992a). ESD principles have since been included in various pieces of South Australian legislation, both prior to the Rann Labour Government coming to power (e.g., the Environmental Protection Act (SA, 1993b)), and during its term of office (e.g., the Aquaculture Act (SA, 2001), Climate Change and Greenhouse Reduction Bill (SA, 2007b), and Marine Parks Act (SA, 2008a)), and are referred to in varying degrees of detail in a broad array of SAG documents (see Figure 5).

Despite its 'Ecological' prefix, the ESD and mainstream (Reformist-based) sustainable-development terminologies are fundamentally the same, evident in particular by: (a) both being defined in anthropocentric terms of sustaining human development as opposed to a broader ecocentric wellbeing approach, and (b) both having a strong focus on continued economic growth to progress human wellbeing. Further, these two terms are used interchangeably in the literature (e.g., Diesendorf, 2000; Harding, 2006), and, specifically within the SAG context, some SAG documents (e.g., SAG, 2005a; 2008c; 2008d) define ESD using the most common sustainable-development definition, namely "development that meets the needs of the present without compromising the ability of future generations to meet their own needs" (Dovers, 2005; Gould \& Lewis, 2009; Wissenburg, 2001).

In these respects, and in accordance with expectations, the SAG's core sustainable-world language Ecologically Sustainable Development - is, despite its 'Ecological' prefix, consistent with the key themes of mainstream Reformist sustainable-development terminology.

\subsubsection{Attaining Sustainability}

The second dominate SAG sustainability concept is 'Attaining Sustainability', which gains its importance from being one of the 6 core objectives set out in South Australia's Strategic Plan (State-plan) (SAG, 2007v) (the State-plan is discussed further in section 4.2). The Attaining Sustainability concept is, however, peculiar as it is concerned almost exclusively with environmental issues where "the Attaining Sustainability objective focuses on attaining environmental sustainability: a healthier River Murray, reduced energy consumption and greenhouse emissions, and protection of land and marine biodiversity" (SAG, 2006h, p. 40).

The key point is that despite sustainability terminologies within the SAG including a range of ecological, economic, and social factors, and despite the idea of ESD being based on sustaining human development in ecologically responsible and socially just ways, the Attaining Sustainability concept narrows sustainability issues to being mostly concerned with environmental matters. One implication of this is that a comprehensive understanding of the SAG's sustainable-world approach needs to be found beyond what is contained within its Attaining Sustainability narrative, an issue which is addressed in the case study research through a review of the SAG's broader set of policies, plans, and goals.

\subsection{The sustainable-world typology}

Consistent with expectations, the SAG's broader policies, plans, and goals show, other than for two noted areas of divergence (discussed further below), a strong consistency with Reformism. A core strategic document illustrating this Reformist position is South Australia's Strategic Plan (State-plan) (SAG, 2007v). The State-plan, first released by the Rann Labour Government in 2004, is the key document summarising the strategies on which the SAG is focused. This plan sets out a series of targets based around 6 core objectives namely:

1) Growing Prosperity.

2) Improving Wellbeing.

3) Attaining Sustainability.

4) Fostering Creativity and Innovation.

5) Building Communities.

6) Expanding Opportunity.

The State-plan is also instructive for gaining a summary picture of the SAG's strategies as many of the reports and planning documents produced by SAG departments link their content to State-plan targets (e.g., SAG, 2007b; 2007f; 2007k; 2007q), whilst other SAG reports have formed the basis of targets that have been included in the State-plan (e.g., the SAG report "Prosperity Through People - A Population Policy for South Australia" (SAG, 2004e) links to the SASP population target). 
A strong theme in the State-plan is the drive for economic growth, with the Plan's first target, listed under "Objective 1, Growing Prosperity", being to "exceed the national economic growth rate by 2014". Strategies to achieve this growth include increasing South Australia's attractiveness to business by way of cost competitiveness, increasing exports in the broad sense, and growing specific industry sectors including defence, mining, tourism, and education. The State-plan also sets out clear population growth goals that link to the economic growth agenda. Although the SAG has also targeted other industry sectors to underpin South Australia's economic growth, including developing a green-technology and renewable energy sector (Emmerson, 2009; SAG, 2009d, 2009f), the general push for GDP-measured economic growth, supported by Reformist narratives remains a dominant theme (e.g., SAG, 2007v; 2009e; 2009g).

This focus on Reformist based economic growth does not mean the SAG ignores social and ecological issues. To the contrary, a broad range of initiatives are evident in the State-plan and other SAG documents, and in legislation enacted during the Rann Labour Government's terms of office, that directly address these issues. Examples include: (a) the passing of legislation to reduce green-house-gas emissions (SA, 2007b), (b) strategies to increase South Australia's generation and consumption of renewable, as compared to fossil-fuel based, energy (SAG, 2008e, 2009b, 2009c), (c) the establishment of marine parks and nature corridors to help address problems of species loss (SA, 2007a; SAG, 2007o, 2007p), (d) reducing waste to landfill (SA, 2004; SAG, $2005 \mathrm{~h}, 2010$ ), and (e) various social equity initiatives, particularly in the form of 'social inclusion' (Cappo, 2008; SAG, 2007v). The point is, however, that these initiatives are all conducted within the context of a focus on human wellbeing progressed through strong and unlimited green-and-just economic growth, typical of the Reformist-approach.

Two noted areas that have some degree of divergence from both the Reformist and Transformational approaches, relate to human population and defence. First, for population, the State-plan has a clear population growth target for South Australia through to the year 2050, based on policies of fertility-rate increase, increased immigration, and reduced emigration (SAG, 2004e, 2007v). The Reformist narrative on human population is, however, focused on population stabilisation as opposed to deliberate strategies to increase population numbers and, alternately, the Transformational-approach seeks long-term population reduction (Clifton, 2010b).

The second issue, defence, concerns the SAG's focus on building the defence sector as an important element of South Australia's economic base (Kelton, 2010; SAG, 2007v, 2008a, 2009a). Although both the Reformist and Transformational-approaches include the continued existence of some degree of National defence capability, both call for reductions in military spending and a reallocation of society's resources to human and ecological wellbeing initiatives. It is difficult to reconcile the implications of a deliberate drive to grow a defence industry against these sustainable-world calls for reductions in military spending (Clifton, 2009, 2010b).

\subsection{Footprint-Analysis, and $I=P A T$}

An I=PAT assessment of the SAG's strategies shows:

'P': A strategy to grow South Australia's population as per State-plan target T1.22: "increase South Australia's population to 2 million by 2050, with an interim target of 1.64 million by 2014" (SAG, 2007v).

'A': A strategy to grow the South Australian economy as per State-plan target T1.1: "exceed the national economic growth rate by 2014" (SAG, 2007v).

' $T$ ': A strong focus on innovation and technology solutions to progress the wellbeing of South Australia's citizens (SAG, 2007v).

Other than the concerns expressed in section 4.2 relating to the SAG's population strategy, this I=PAT representation, as per the discussion in section 2.3.1, also sees the SAG sustainable-world approach as consistent with Reformism.

South Australia's summary Footprint-Analysis data is shown as Figure 6. An assessment of this data in terms of the four tests set out in section 2.4 to consider the local-in-terms-of-the-global, shows:

(1) Consumption-based Ecological-Footprint vs local Biocapacity: South Australia's citizens, with an average Ecological-Footprint of 7.0ghpc, are currently not living within South Australia's Biocapacity limits of $3.8 \mathrm{ghpc}$ (after allowance is made for Biocapacity that is not available for human use).

(2) Production-based Ecological-Footprint vs local Biocapacity: Data on South Australia's production-based measure is not available so no conclusions can be drawn. 
(3) Fair-Earth-share: South Australia's citizens, with an average Ecological-Footprint of 7.0ghpc, are not living within fair-Earth-share Biocapacity limits of $1.8 \mathrm{ghpc}$ or, more appropriately, $0.9 \mathrm{ghpc}$ after allowing for Biocapacity not available for human use (see Figure 2).

(4) Generalisation test: In not meeting the fair-Earth-share requirements, the South Australian community also fails the generalisation test (Note: other generalisation issues are considered below).

These findings show that, from a Footprint-Analysis perspective, the South Australian community is current not living in a way consistent with a global sustainable-world goal and, in this respect, is detracting from achievement of this goal.

\section{<insert Figure 6 here>}

The SAG is aware that South Australia's current Ecological-Footprint is unacceptably high (SAG, 2006g, 2007n, $2007 \mathrm{v}$ ). As part of its Attaining Sustainability objective, the SAG has set a goal of reducing the aggregate South Australian Ecological-Footprint by 30\% by the year 2050 (SAG, 2007v). Based on the SAG's current population growth target as set out in the State-plan, this translates into a per capita Ecological-Footprint value by 2050 of 3.7ghpc. The population growth strategy also has an impact of eroding South Australia's per capita available Biocapacity value, with modified Biocapacity values included in the summary Footprint-Analysis data for South Australia, based on the SAG's Ecological-Footprint and population goals, shown as Figure 7. Applying the Figure 7 data to the local-in-terms-of-the-global tests shows that, if the SAG's Ecological-Footprint reduction goal was achieved:

(1) Consumption-based Ecological-Footprint vs local Biocapacity: South Australia's citizens, with an average Ecological-Footprint of $3.7 \mathrm{ghpc}$, would still be living beyond South Australia's Biocapacity limits of 2.9 ghpc (after allowance is made for Biocapacity that is not available for human use).

(2) Production-based Ecological-Footprint vs local Biocapacity: Data is not available.

(3) Fair-Earth-share: South Australia's citizens would still be living beyond fair-Earth-share Biocapacity limits which, as shown in Figure 3, is estimated by 2050 to be approximately $1.3 \mathrm{ghpc}$ or, more appropriately, 0.7ghpc after allowing for Biocapacity not available for human use.

(4) Generalisation test: In not meeting the fair-Earth-share requirements, the South Australian community also fails the generalisation test (Note: other generalisation issues are considered below).

These findings show that, even if the SAG's Ecological-Footprint reduction goal was achieved, the South Australian community would, by the year 2050, still not be living sustainably in Footprint-Analysis terms and hence would continue to detract from a global sustainable-world goal.

\section{$<$ insert Figure 7 here>}

\section{Discussion}

\subsection{Overview}

This paper has reported on the findings of a case study of the South Australian Government's (SAG's) sustainable-world approach. In summary, these findings show that the SAG's approach is, for the most, firmly placed in the Reformist view, providing specific case study support to existing literature claims of Reformism's dominance in the political domain. Two noted areas of divergence from the Reformist-approach were identified, they being the SAG's population and defence industry strategies. Neither of these are a comfortable fit to the Reformist-approach and both are well removed from the Transformational-approach. The South Australian community is also shown to not be living sustainably in Footprint-Analysis terms and, in this respect, is detracting from a global sustainable-world goal. The SAG's Ecological-Footprint reduction goal will not resolve this problem. The Project's broader findings - through application of Footprint Analysis in conjunction with $\mathrm{I}=\mathrm{PAT}$, and application of the socio-ecological-resilience concept - that show Reformism as challenging to accept as a viable pathway for humanity to progress a sustainable-world outcome, similarly apply in the SAG setting. In this respect, the issue for the SAG is not how well it is performing in progressing its strategies, but rather that it needs to reconsider the strategies themselves.

A number of general limitations apply to the findings reported in this paper, in particular: (a) its single case study approach and the constrained nature of the findings that are inherent in such an approach, (b) the document analysis method which may have limited the findings as compared to incorporating a broader set of data sources, such as interviews of parties within and external to the SAG, and (c) the limitations that apply to the findings of Project Q1. The Q1 limitations and their implications are detailed in other papers and include: (a) the categorisation of sustainable-world approaches into only the Reformist and Transformational formulations 
(Clifton, 2010b), (b) uncertainty concerning accuracy of aspects of the Footprint-Analysis data and how the I=PAT components interact (Clifton, 2010d), and (c) the limited extent to which the socio-ecological-resilience concept has been developed in the literature in respect to the full range of sustainable-world dimensions that constitute the Reformist and Transformational approaches (Clifton, 2010a).

In the remainder of this section, some of the key issues identified from the SAG case study are discussed, together with some comments on other limitations of the study and areas for future research.

\subsection{Sustainability language}

The findings show that sustainability language is well embedded within the SAG. Two key areas that the research has not explored in this sustainability-language review are noteworthy.

First is that the SAG's Attaining Sustainability concept is mostly concerned with environmental issues. The possible implications of this, which may also extend to use of the 'Ecological' prefix in the SAG's use of sustainable-development language, has not been considered. This presents an area where further research may prove beneficial, particularly in considering whether this environmental focus of the SAG's sustainability language is supported by governance and institutional structures within the SAG that impair its performance in attending to the broader range of sustainable-world dimensions shown in Figure 1, in particular, the interactions and interdependencies between these dimensions.

Second, is that the research has not considered whether the use of sustainability terminology by the SAG is more rhetoric than substantive. That is, the research focused on the SAG's policies, plans, and goals from a sustainable-world perspective, and did not look at the actual performance of the SAG in achieving its stated objectives. This raises a question as to whether this focus on strategies, as opposed to performance in achieving goals, is a material limitation of the study. The answer to this question is no, the reason being that the issue at stake for the Project is not how well the SAG is performing in pursuing its sustainability agenda, but rather, what agenda it is pursuing. The Project proposes that Reformism itself is troublesome and, particularly from a socio-ecological-resilience perspective, is in some respects self defeating. As such, whether the SAG is performing well in advancing its Reformist oriented strategies is somewhat irrelevant to the issue at hand. Although not dismissing the possible value that may come from putting the SAG's claims of sustainability leadership to the test, a more purposeful area for future research may instead be one focused on how a government such as the SAG can help transition society to a sustainable-world outcome in a way that is not subject to the inherent risks and self-defeating characteristics of Reformism.

\subsection{The sustainable-world typology}

The sustainable-world typology developed as part of the Project adds to the existing literature by, amongst other things, providing a comprehensive framework by which the sustainable-world approach of a unit of focus can be assessed, as evidenced by the SAG analysis (for a summary of other knowledge contributions of this typology, see Clifton (2010b)). The two key areas of interest that arose from the use of this typology in the SAG setting relate to the SAG's population and defence industry strategies.

A review the SAG's population policy, including the reasons given for pursuing it, and a brief assessment of the policy from a sustainable-world perspective, is shown in Clifton (2010e) and this detail will not be repeated here. The key point from this review is that it is the SAG's apparent fundamental belief in the benefits of population growth to underpin the economic growth it sees as necessary to further the wellbeing of the South Australian community, that raises concerns within the global sustainable-world context. Population growth cannot go on forever (although it should be noted that the SAG's population strategy will still see the South Australian population continue to grow beyond the current 2050 target date (SAG, 2006f) with no evidence apparent in SAG documents of plans to cease this growth). When looked at in terms of the generalization test shown in section 2.4, it is challenging to see how a policy of deliberate and open-ended population growth can be justified in the global sustainable-world setting. This becomes an even more challenging issue when looked at within the Footprint-Analysis context, a matter which is addressed below. Despite this, and although acknowledging the sustainability challenges a growing population may create (SA-EDB, 2003; SAG, 2006f), the SAG nonetheless presents its population strategy as not only consistent with sustainable-world objectives, but in many ways beneficial to it (SA-EDB, 2007; SAG, 2004e, 2006f).

The SAG document analysis did not reveal if the SAG's views on the need for population growth extend to the broader global context, or if it instead sees the South Australian setting as a special case deserving differential treatment. Further research on this issue would be useful to better understand the extent to which the SAG's 
population strategy is credible in the global sustainable-world context or, alternately, if it is more of a narrow self-interest strategy legitimised with sustainability rhetoric.

In relation to the SAG's defence industry strategy, responsibility for Australia's defence activities rest with the Federal Government and hence, South Australia cannot develop its own armed forces capability. The SAG is, however, aggressively pursuing the defence sector as an important element of South Australia's economic base demonstrated by: (a) the SAG setting a series of targets in South Australia's Strategic Plan to substantially grow the sector in both value and employment uptake (SAG, 2007v), (b) the creation of a unit - Defence SA - with a specific purpose to promote South Australia's defence industry capability (see SAG (2008b)), and (c) the issuing of regular public statements celebrating the opportunities for, and securing of, new defence contracts (e.g., SAG, 2008b, 2008g, 2009a; 2009h). It might be argued that this is a defence, not aggression, issue, and that as defence contracts will be awarded regardless of whether the work is conducted within South Australia or elsewhere, it would be foolhardy for the SAG to simply ignore this economic opportunity. But this is hardly the point. It is difficult to see how the SAG, or any other government body in a similar position, can engage in any meaningful public dialogue that calls for reductions in military spending and otherwise publicly denounce continued militarism, whilst actively seeking to grow the sector as a key economic plank. The SAG nonetheless appears to see no conflict between its defence sector objectives and its sustainability credentials and, as for population growth, couches its defence industry objectives in sustainability language (e.g., SAG, 2008h; 2008i; 2009a).

The SAG case study did not explore beyond document content analysis how the SAG sees its defence industry strategy within the context of the Reformist and Transformational narratives that call for reductions in military spending. As for the population issue, further research in this area would be useful to better understand the extent to which the SAG's defence industry strategy is credible from a sustainable-world perspective, or whether sustainability language is used to instead justify local economic advantage at the expense of a global sustainable-world objective. In a world of escalating military expenditure (Archer, 2005; SIPRI, 2008; UNGO, 2008; UNSC, 2008), this further research within the SAG setting may also provide some useful insights into similar issues in other government settings.

\subsection{Footprint-Analysis, and $I=P A T$}

The Footprint-Analysis critique of the SAG's sustainable-world approach adds to the existing literature by providing a working example of how Footprint-Analysis can be used to assess a local setting in terms of a global sustainable-world goal. The assessment shows that the SAG's Ecological-Footprint reduction target is far too modest and, even if achieved, will not see the South Australian community live in ways consistent with a global sustainable-world objective. Instead, over the next 40 years and beyond, the South Australian community will, amongst other things, (a) perpetuate injustice by maintaining a privileged use of the Earth's resources beyond fair-Earth-share levels, and (b) remain a net contributor to the degradation of the Earth's renewable natural resource base which harms future generations, undermines ecosystem wellbeing, and detracts from socio-ecological system resilience. As such, and despite the SAG's claims of sustainability leadership, this Footprint-Analysis assessment tells a story of persistent unsustainable behaviour by the South Australian community.

The SAG's population and economic growth policies also pose two other significant problems within the Footprint-Analysis context. The first is that a growing population is Biocapacity eroding in the sense that it reduces the per capita Biocapacity that is available for human use and hence reduces the global fair-Earth-share Biocapacity value. As such, the SAG is not only targeting an inadequate Ecological-Footprint value, the situation is aggravated by the SAG's population growth strategy that erodes the fair-Earth-share Biocapacity value, hence increasing the magnitude of the Ecological-Footprint reduction challenge humanity faces. When the factors of: (a) the current unsustainable South Australian Ecological-Footprint, (b) the inadequacy of the SAG's Ecological-Footprint target, and (c) Biocapacity erosion through the SAG's population growth strategy, are combined and considered in terms of the generalisation-test discussed in section 2.4, the SAG's sustainability leadership claims are far from convincing. The second issue is that, even if the SAG were to set a more appropriate Ecological-Footprint reduction goal, its commitment to Reformism is unlikely to see this goal achieved.

As mentioned in section 4.3, the SAG is aware of the unacceptably high Ecological-Footprint of the South Australian community, however the reasons the SAG decided on its current reduction goal and how this goal is reconciled with sustainable-world objectives has not been explored as part of the case study research. This is an area where further research may be beneficial, to not only better understand the SAG's position, but more 
importantly to explore how the SAG might go about setting an appropriate Ecological-Footprint target supported by credible strategies for its achievement.

\section{Conclusion}

The central theme running through the Project on which this paper is based, and in the discussion of the SAG case study, is that Reformism dominates as a sustainable-world narrative in the social power centres of government and business, and that this approach is unconvincing as a viable pathway to see the primary sustainable-world goal - the flourishing of life, incorporating human and ecological wellbeing, maintained over an indefinite time frame - achieved. A number of authors make a point that, irrespective of any evidence supporting the need for a more Transformational-approach to progress a sustainable-world outcome, most governments are, currently at least, locked in to supporting the current neo-liberal economic growth agenda (Cato, 2009; Jackson, 2009; McManus, 1996; Robinson, 2004). In addition, Reformism's dominance in the political and business domains is also seen to exist to the exclusion of alternate narratives. That is, to be heard politically and by business, proposals to progress the achievement of a sustainable-world must fit the Reformist (i.e., mainstream sustainable-development) view (Dauvergne, 2008; Gould et al., 2008; Kallio, Nordberg, \& Ahonen, 2007; McGregor, 2004).

These three issues - Reformism's questionable viability, governments seemingly locked in to pursuing Reformism's core economic strategies, and the delegitimising of alternate narratives - create a challenging mix in seeing society undertake the change needed for a successful sustainable-world transition. It has not been the purpose of this paper to explore how society might go about making such a transition. However, with the current dominant Reformist-approach advocated by the politically and economically powerful actors in society government and business - and, as alluded to above, it is these parties that currently determine which sustainable-world narratives are deemed legitimate, then change ultimately needs to occur within these spheres of power. Whether a government such as the SAG is willing and able to begin a process of such change in its own policy processes, and if it is willing, how it might do so, remains an open issue and something the SAG may be able to take from the Project's findings for its further consideration.

\section{References}

AG. (1992a). Intergovernmental Agreement on the Environment: Australian Government, 1 May 1992.

AG. (1992b). National Strategy for Ecological Sustainable Development. Canberra: Australian Government, December 1992.

Agrawal, M., Boland, J., \& Filar, J. A. (u.d.). The Ecological Footprint of South Australia. Adelaide: University of South Australia.

Alcott, B. (2008). The Sufficiency Strategy: Would Rich-World Frugality Lower Environmental Impact? Ecological Economics, 64(4), 770-786.

Archer, C. (2005). Warfare or Welfare: Disarmament for Development in the 21st Century. Geneva, Switzerland: International Peace Bureau.

Braun, V., \& Clarke, V. (2006). Using Thematic Analysis in Psychology. Qualitative Research in Psychology, 3, $77-101$.

Cappo, D. (2008). Six Years On: A Review of South Australia's Social Inclusion Initiative: Address to the Don Dunstan Foundation, Adelaide Monday, 21 April 2008.

Castro, C. J. (2004). Sustainable Development. Organization \& Environment, 17(2), 195-225.

Cato, M. S. (2009). Green Economics. London: Earthscan.

Chertow, M. R. (2000). The IPAT Equation and Its Variants. Journal of Industrial Ecology, 4(4), 13.

Clifton, D. (2009). Security and a Sustainable World. Journal of Sustainable Development, 2(3), 3-17.

Clifton, D. (2010a). Progressing a Sustainable World - a Socio-ecological Resilience Critique. Journal of Sustainable Development, in press.

Clifton, D. (2010b). Representing a Sustainable World - A Typology Approach. Journal of Sustainable Development, 3(2), 40-57.

Clifton, D. (2010c). Sustainability and Government - A Case Study of the South Australian Government. Journal of Environment and Ecology, 1(1), 1-27. 
Clifton, D. (2010d). A Sustainable World - an Ecological Footprint and I=PAT Perspective. Journal of the Asia-Pacific Centre for Environmental Accountability, 16(2), 3-26.

Clifton, D. (2010e). A Sustainable-World - The Local in Terms of the Global: An Ecological Footprint Analysis Perspective. Journal of the Asia-Pacific Centre for Environmental Accountability, 16(3), in press.

Dauvergne, P. (2008). The Shadows of Consumption. Cambridge, MA, USA: MIT Press.

Diesendorf, M. (2000). Sustainability and Sustainable Development. In D. C. Dunphy, J. Benveniste, A. Griffiths \& P. Sutton (Eds.), Sustainability: The Corporate Challenge of the 21st Century (pp. 19-37): Allen \& Unwin.

Dobson, A. (1996). Environmental Sustainabilities: An Analysis and a Typology. Environmental Politics, 5(3), 401-428.

Dovers, S. R. (2005). Environment and Sustainability Policy: Creation, Implementation, Evaluation. Leichhardt, NSW: The Federation Press.

Emmerson, R. (2009). The State Government will set up a \$20 million fund in Thursday's Budget to create South Australia's renewable energy industry: AdelaideNow on-line news service at http://www.news.com.au/adelaidenow/story/0,22606,25575205-2682,00.html?referrer=email\&source=AN_emai $1 \_n l, 2$ June 2009.

Folke, C. (2006). Resilience: The Emergence of a Perspective for Social-Ecological Systems Analyses. Global Environmental Change, 16, 253-267.

Footprint Network. (2006). Ecological Footprint Standards 2006: The Footprint Network: Global Footprint Network Standards Committees.

Footprint Network. (2009). Ecological Footprint and Biocapacity 2006 data release (based on National Footprint Accounts 2009 edition). Footprint Network.

Footprint Network. (2010). Ecological Footprint: Footprint Network web site at http://www.footprintnetwork.org/.

Fox, W. (2003). Deep Ecology: A New Philosophy of Our Time (reproduced from "The Ecologist" 1984). In A. Light \& H. Rolston (Eds.), Environmental Ethics (pp. 252-261). Oxford, UK.: Blackwell Publishers Ltd.

Giljum, S., Hammer, M., Stocker, A., Lackner, M., Best, A., Blobel, D., et al. (2007). Scientific Assessment and Evaluation of the Indicator "Ecological Footprint": Environmental Research of the Federal Ministry of the Environment, Nature Conservation and Nuclear Safety. Research Report 36301 135, UBA-FB 001089/E.

Gould, K. A., \& Lewis, T. L. (2009). The Paradoxes of Sustainable Development. In K. A. Gould \& T. L. Lewis (Eds.), Twenty Lessons in Environmental Sociology (pp. 269-289). New York: Oxford University Press.

Gould, K. A., Pellow, D. N., \& Schnaiberg, A. (2008). The Treadmill of Production. Boulder, Colorado USA: Paradigm Publishers.

Handmer, J. W., \& Dovers, S. R. (1996). A Typology of Resilience: Rethinking Institutions for Sustainable Development. Industrial and Environmental Crisis Quarterly, 9(4), 482-511.

Harding. (2006). Ecologically Sustainable Development: Origins, Implementation and Challenges. Desalination, $187,229-230$.

Holdren, J. P., Daily, G. C., \& Ehrlich, P. R. (1995). The Meaning of Sustainability: Biogeophysical Aspects. Washington DC: United Nations University and The World Bank.

Holling, C. S. (1996). Engineering Resilience versus Ecological Resilience. In P. C. Schulze (Ed.), Engineering Within Ecological Constraints (pp. 31-44). Washington, D.C.: National Academy Press.

Jackson, T. (2009). Prosperity Without Growth. London: Earthscan.

Kallio, T. J., Nordberg, P., \& Ahonen, A. (2007). Rationalizing Sustainable Development - A Critical Treatise. Sustainable Development, 15(1), 41-51.

Kelton, G. (2010). Defence Training Hub Announced by SA Premier Mike Rann: AdelaideNow on-line news service

http://www.adelaidenow.com.au/news/in-depth/defence-training-hub-announced-by-sa-premier-mike-rann/storye6frebnu-1225835621345, 1 March 2010. 
Kitzes, J. (2007, 8-10 May 2007). A Research Agenda for Improving National Ecological Footprint Accounts. Paper presented at the International Ecological Footprint Conference: Stepping Up the Pace - New Developments in Ecological Footprint Methodology, Policy and Practice, Cardiff.

Kitzes, J., Peller, A., Goldfinger, S., \& Wackernagel, M. (2007). Current Methods for Calculating National Ecological Footprint Accounts. Science for Environment \& Sustainable Society, 4(1).

Madore, D. (2006). Nietzsche's Conception of Life as Overcoming. In E. Laferriere \& P. J. Stoett (Eds.), International EcoPolitical Theory: Critical Approaches. Vancouver: UBC Press.

Manderson, A. K. (2006). A Systems Based Framework to Examine The Multi-Contextual Application of the Sustainability Concept. Environment, Development and Sustainability, 8, 85-97.

McGregor, A. (2004). Sustainable Development and 'Warm Fuzzy Feelings': Discourse and Nature Within Australian Environmental Imaginaries. Geoforum, 35(5), 593-606.

McManus, P. (1996). Contested Terrains: Politics, Stories and Discourses of Sustainability. Environmental Politics, 5(1), 48-73.

Meadows, D. H., Randers, J., \& Meadows, D. (2004). Limits to Growth: The 30-Year Update. White River Junction: Chelsea Green Publishing Company.

Naess, A. (2003). The Deep Ecological Movement: Some Philosophical Aspects (reproduced from "Philosophical Inquiry" 1986). In A. Light \& H. Rolston (Eds.), Environmental Ethics (pp. 262-274). Oxford, UK.: Blackwell Publishers Ltd.

Nurse, K. (2006). Culture as the Fourth Pillar of Sustainable Development: UN Food and Agriculture Organisation - Sustainable Agriculture and Rural Development Initative.

Parkin, A. (2006). Understanding Liberal-Democratic Politics. In A. Parkin, J. Summers \& D. Woodward (Eds.), Government, Politics, Power and Policy in Australia (6 ed., pp. 3-24). New South Wales: Pearson Education Australia.

Polimeni, J. M., Mayumi, K., Giampietro, M., \& Alcott, B. (2009). The Myth of Resource Efficiency. London: Earthscan.

Porritt, J. (2005). Capitalism As If The World Matters. London: Earthscan.

Princen, T. (2005). The Logic of Sufficiency. Cambridge MA, USA: MIT Press.

Robinson, J. (2004). Squaring the Circle? Some Thoughts on the Idea of Sustainable Development. Ecological Economics, 48, 369-384.

SA. (1993a). South Australian Development Act 1993 (27 Sept 2007 version).

SA. (1993b). South Australian Environmental Protection Act 1993.

SA. (2001). South Australia Aquaculture Act 2001, Version 1.7.2005.

SA. (2003a). South Australia Constitution Act 1934, Version 24 November 2003.

SA. (2003b). South Australia River Murray Act 2003.

SA. (2004). South Australia Zero Waste SA Act 2004.

SA. (2007a). South Australia Marine Parks Bill 2007.

SA. (2007b). South Australian Climate Change and Greenhouse Reduction Bill 2007.

South Australia Marine Parks Act 2007 (version 22/5/2008), (2008a).

SA. (2008b). South Australia Marine Parks Act 2007 (version 22/5/2008).

SA-EDB. (2003). A Framework for Economic Development in South Australia: South Australia's Economic Development Board.

SA-EDB. (2007). Economic Update - 2007: South Australian Economic Development Board, November 2007.

SAG. (2003a). NatureLinks: Implementing the WildCountry Philosophy in South Australia: South Australian Government, February 2003.

SAG. (2003b). Planning Strategy for Regional South Australia: South Australian Government, January 2003.

SAG. (2004a). Aquaculture Licensing and Leasing Policy Report. Adelaide: SA Government: Primary Industries and Resources South Australia, 4 March 2004. 
SAG. (2004b). Aquaculture Resource Management and Ecologically Sustainable Development Policy. Adelaide: SA Government: Primary Industries and Resources South Australia, 12 August 2004.

SAG. (2004c). EPA Information: Eco-Efficiency and the Private Sector: South Australian Government, March 2004.

SAG. (2004d). Greening of Government Operations (GOGO) Framework 2004: South Australian Government.

SAG. (2004e). Prosperity Through People - A Population Policy for South Australia. Adelaide: South Australian Government, March 2004.

SAG. (2004f). SA Water Sustainability Policy: South Australian Government.

SAG. (2005a). Background Paper to South Australia's Waste Strategy 2005-2010: South Australian Government - Zero Waste SA.

SAG. (2005b). DTED Strategic Directions 2005-2008: South Australian Government, Department of Trade and Economic Development.

SAG. (2005c). Eastern Spencer Gulf Aquaculture Management Policy Report. Adelaide: SA Government: Primary Industries and Resources South Australia, 15 Dec 2005.

SAG. (2005d). Environmental Protection Authority Strategic Plan 2005-2008: South Australian Government.

SAG. (2005e). Government's Progress on Creating a Sustainable Adelaide: South Australian Government Department for Environment and Heritage, February 2005.

SAG. (2005f). The Role of the EPA in Attaining Sustainability: South Australian Government Environmental Protection Authority, October 2005.

SAG. (2005g). Social Sustainability Partnership Agreement: South Australian Government and The Adelaide City Council, June 2005.

SAG. (2005h). South Australia's Waste Strategy 2005-2010. Adelaide: South Australian Government - Zero Waste SA.

SAG. (2006a). Climate Change and Greenhouse Emissions Reduction Bill 2006: Consultation Draft: Explanatory Paper and Request for Comments: SA Government, June 2006, Sustainability and Climate Change Division.

SAG. (2006b). Environmental Protection Authority Annual Report 2005-2006: South Australian Government.

SAG. (2006c). An Environmental Sustainability Framework for SA: Working Brief: South Australian Government: Sustainability and Climate Change Division, 31 October 2006.

SAG. (2006d). Good Business (No. 1921018941): SA Government, Premier's Round Table on Sustainability.

SAG. (2006e). Greening of Government Operations (GOGO) Action Plan: South Australian Government, 13 February 2006.

SAG. (2006f). Planning Strategy for Metropolitan Adelaide: South Australian Government, August 2006.

SAG. (2006g). South Australia's Ecological Footprint: SA Government: Sustainability and Climate Change Division of the Department of the Premier and Cabinet, May 2006.

SAG. (2006h). South Australia's Strategic Plan - Progress Report 2006: SA Government, June 2006.

SAG. (2006i). State Natural Resource Management Plan 2006: South Australian Government, February 2006.

SAG. (2007a). Adelaide Capital City Project. Retrieved 30 July, 2007, from http://www.capcity.adelaide.sa.gov.au/

SAG. (2007b). DEH Annual Report 2006-2007: South Australian Government - Department for Environment and Heritage.

SAG. (2007c). Department for Environment and Heritage Corporate Plan 2007/2010: South Australian Government.

SAG. (2007d). Department for Environment and Heritage Web Site. Retrieved 14 September, 2007, from http://www.environment.sa.gov.au/

SAG. (2007e). Department of Education and Children's Services Annual Report 2007: South Australian Government. 
SAG. (2007f). Department of the Premier and Cabinet: Annual Report 2006-07. Adelaide: South Australian Government.

SAG. (2007g). Department of Water, Land and Biodiversity Conservation: Corporate Plan 2007-2011: South Australian Government.

SAG. (2007h). Department of Water, Land and Biodiversity Conservation: Web Site. Retrieved 28 August, 2007, from http://www.dwlbc.sa.gov.au/

SAG. (2007i). DFC Annual Report 2006-2007: South Australian Government Department for Families and Communities.

SAG. (2007j). DFEEST Strategic Plan 2007-2010: South Australian Government Department of Further Education, Employment, Science and Technology.

SAG. (2007k). DTED Annual Report 2006-2007: South Australian Government Department of Trade and Economic Development.

SAG. (20071). DTEI's Green Plan - Response to Greening of Government Action Plan: South Australian Government Department for Transport, Energy and Infrastructure, June 2007.

SAG. (2007m). EPA Strategic Plan 2007-2010: South Australian Government Environmental Protection Authority.

SAG. (2007n). Fact Sheet: A Summary of Government of South Australia Sustainability and Climate Change Initiatives: South Australian Government, October 2007.

SAG. (2007o). Marine Parks Centre of Environment Investment. Adelaide: SA Government, Media Release: Budget 2007-2008, 7 June 2007.

SAG. (2007p). No Species Loss: A Biodiversity Strategy for South Australia 2007-2017. Adelaide: SA Government, Department for Environment and Heritage, May 2007.

SAG. (2007q). PIRSA Annual Report 2006-2007: South Australian Government Primary Industries and Resources South Australia.

SAG. (2007r). SA Department of Water, Land and Biodiversity Conservation: Annual Report 2006-07: South Australian Government.

SAG. (2007s). SA Environmental Protection Agency: Web Site. Retrieved 28 August, 2007, from http://www.epa.sa.gov.au/

SAG. (2007t). South Australia Economic Development Board. Adelaide: South Australian Government: Department of Trade and Economic Development web site at: http://www.southaustralia.biz/About-DTED/Boards-and-Councils.aspx\#EDB, accessed 4 Dec 2007.

SAG. (2007u). South Australia's State Strategic Plan Web Site. Retrieved 14 October, 2007, from http://www.stateplan.sa.gov.au/

SAG. (2007v). South Australia's Strategic Plan 2007: SA Government, January 2007.

SAG. (2007w). Zero Waste SA: Business Plan 2007-2008. Adelaide: South Australian Government - Zero Waste SA.

SAG. (2008a). Defence Strategy: South Australian Government - Defence SA.

SAG. (2008b). Defense SA Web Site. Retrieved 21 June, 2008, from http://www.defence-sa.com/

SAG. (2008c). DTEI Web Site. Retrieved 21 June, 2008, from http://www.dtei.sa.gov.au/index.html/

SAG. (2008d). PIRSA Web Site. Retrieved 10 June, 2008, from http://www.pir.sa.gov.au/

SAG. (2008e). Premier Rann's Speech to the 3rd International Solar Cities Congress, Adelaide, South Australia, 18 February 2008: South Australian Government.

SAG. (2008f). Six Years On: A Review of South Australia's Social Inclusion Initiative: South Australian Government, Speech by Premier Rann to the Don Dunstan Foundation, Adelaide Monday, 21 April 2008.

SAG. (2008g). South Australia - A Brilliant Blend: South Australian Government, May 2008.

SAG. (2008h). South Australia's State Strategic Plan - Target Fact Sheets 2008. Retrieved 28 February, 2009, from http://www.saplan.org.au/

SAG. (2008i). State Budget Papers 2008-2009: South Australian Government. 
SAG. (2008j). State of the Environment Report for South Australia 2008: South Australian Government Environmental Protection Authority.

SAG. (2009a). Big Pitch for Submarine Design Centre: South Australian Government - Department of Trade and Economic Development http://www.southaustralia.biz/News/2009/12/15/Big-pitch-for-Submarine-Design-Centre.aspx 15 Dec 2009.

SAG. (2009b). Electrifying Approach to Green Energy: South Australian Government - Department of Trade and Economic Development

http://www.southaustralia.biz/News/2009/10/12/Electrifying-approach-to-green-energy.aspx, 12 Oct 2009.

SAG. (2009c). Green energy hub for South Australia: South Australian Government - Department of Trade and Economic Development http://www.southaustralia.biz/News/2009/08/21/Green-energy-hub-for-South-Australia.aspx, 21 Aug 2009.

SAG. (2009d). Green light for cleantech: South Australian Government - Department of Trade and Economic Development at http://www.southaustralia.biz/News/2009/06/23/Green-light-for-cleantech.aspx, 23 June 2009.

SAG. (2009e). Ministerial Statement - Response to EDB's Economic Statement: South Australian Government.

SAG. (2009f). Push for Clever Green Investment: South Australian Government - Department of Trade and Economic Development http://www.southaustralia.biz/News/2009/06/09/Push-for-Clever-Green-investment.aspx, 9 June 2009.

SAG. (2009g). Strategic Directions 2009-2014: South Australian Government - Department of Trade and Economic Development.

SAG. (2009h). Work on Next Generation of Submarines. Adelaide: South Australian Government South Australia.biz web site at http://www.southaustralia.biz/News/2009/05/08/Work-on-next-generation-of-submarines.aspx, accessed $14 / 5 / 09$.

SAG. (2010). Zero Waste SA: South Australian Government, Zero Waste SA web site at www.zerowaste.sa.gov.au.

SAG. (u.d.). DTED Corporate Overview: South Australian Government Department of Trade and Economic Development.

SIPRI. (2008). 2008 Yearbook: Armaments, Disarmament and International Security - Summary: The Stockholm International Peace Research Institute; Solna, Sweden.

Speth, J. G. (2008). The Bridge at the End of the World. London: Yale University Press.

UN. (2007). World Population Prospects - 2006 Revision. New York: United Nations - Department of Economic and Social Affairs, Population Division.

UNGO. (2008). Statement by Director-General of UNOG to the Ministerial Review Summit on the Geneva Declaration on Armed Violence and Development. Retrieved 12 September 2008

UNSC. (2008). Security Council Stresses Concern at Increasing Global Military Expenditures, Urges States to Devote 'As Many Resources As Possible' To Development: United Nations Security Council: Media Information Release; SC 9501.

Walker, B., \& Salt, D. (2006). Resilience Thinking: Sustaining Ecosystems and People in a Changing World. Washington DC: Island Press.

WCED. (1987). Our Common Future: World Commission on Environment and Development. Oxford: Oxford University Press.

Williams, C. C., \& Millington, A. C. (2004). The Diverse and Contested Meanings of Sustainable Development. Geographical Journal, 170(2), 99-104.

Wissenburg, M. (2001). Dehierarachization and Sustainable Development in Liberal and Non-Liberal Societies. Global Environmental Politics, 1(2), 95.

Yin, R. K. (2003). Case Study Research: Design and Methods (3rd ed.). California: Sage Publications.

York, R., Rosa, E. A., \& Dietz, T. (2003). STIRPAT, IPAT and ImPACT: Analytic Tools for Unpacking the Driving Forces of Environmental Impacts. Ecological Economics, 46(3), 351-365. 


\section{Figures}

Figure 1. Sustainable-world dimensions

\begin{tabular}{|c|c|}
\hline Sustainable-world dimension & Issues considered \\
\hline 1. Primary sustainable-world goal & What is, for a sustainable-world, to be sustained above all else. \\
\hline 2. Space and time & Spatial and temporal issues relevant to the sustainable-world concept. \\
\hline 3. Satisfaction of interests & $\begin{array}{l}\text { Based on the primary sustainable-world goal having to do with the flourishing of } \\
\text { life through the satisfaction of interests: }\end{array}$ \\
\hline 3.1. Interests: Scope & $\begin{array}{l}\text { Which needs (human and non-human) are to be met, and to what extent are } \\
\text { they to be met to satisfy these interests. }\end{array}$ \\
\hline 3.2. Interests: Mechanism & How these interests are to be satisfied. \\
\hline 3.3. Interests: Population & $\begin{array}{l}\text { For how many human and non-human living things these interests are to be } \\
\text { satisfied. }\end{array}$ \\
\hline 4. Responsibility & $\begin{array}{l}\text { Who is responsible for the current unsustainable state and trajectory of the world, } \\
\text { and who is responsible for remedying it. }\end{array}$ \\
\hline \multicolumn{2}{|l|}{ 5. General principles and concepts } \\
\hline 5.1. Modelling a SW & $\begin{array}{l}\text { How a sustainable-world is modelled in terms of economic, social and ecological } \\
\text { relationships and dependencies. }\end{array}$ \\
\hline 5.2. Justice & Intra and inter-generational justice. \\
\hline 5.3. Human Interests - Resources & Use by, and management of, the Earth's resources by humans. \\
\hline 5.4. Risk and Precaution & Human behaviour in terms of risk and precaution. \\
\hline 5.5. Growth and Development & Economic growth and human development. \\
\hline 5.6. Diversity & Biodiversity and cultural diversity. \\
\hline 5.7. Security & Human security, ecological security, militarism and peace. \\
\hline
\end{tabular}

Source: Clifton (2010b)

Figure 2. Current Footprint-Analysis data

\begin{tabular}{|c|c|}
\hline \multicolumn{1}{|c|}{ Item } & Value \\
\hline 1. Base Footprint-Analysis data (2009 data release) & $2.6 \mathrm{ghpc}$ \\
\hline Ecological-Footprint - average per person for all of humanity. & $1.8 \mathrm{ghpc}$ \\
\hline Total Biocapacity - average per person for all of humanity. & $144 \%$ \\
\hline Ecological-Footprint as a percentage of total Biocapacity. & $0.9 \mathrm{ghpc}$ \\
\hline 2. Footprint-Analysis data after allowing for 50\% of Biocapacity as unavailable for human use ${ }^{\# 1}$ \\
\hline Biocapacity available for human use - average per person for all of humanity. & $289 \%$ \\
\hline Ecological-Footprint as a percentage of Biocapacity available for human use. & \\
\hline
\end{tabular}

Source: Clifton (2010d)

Note \#1: Uncertainty exists regarding the amount of Biocapacity that is safely available for human use. The $50 \%$ value used here as unavailable is an estimate of what may realistically be needed to ensure that ecosystem integrity, consistent with sustainable-world objectives, is maintained. For a detailed discussion on this issue, see Clifton (2010d). 
Figure 3. Reformist-approach: Footprint-Analysis data projected to 2050

\begin{tabular}{|c|c|}
\hline Item & Value \\
\hline \multicolumn{2}{|l|}{ 1. Base data } \\
\hline Current global Ecological-Footprint - average per person for all of humanity. & 2.6 ghpc \\
\hline Projected Biocapacity in 2050 based on global population change only - average per person for all of humanity ${ }^{\# 1 .}$ & $1.3 \mathrm{ghpc}$ \\
\hline \multicolumn{2}{|l|}{ 2. Projections to 2050 with Ecological-Footprint increasing at $50 \%$ of ' $P+A^{\prime}{ }^{\# 2}$} \\
\hline Projected 2050 global Ecological-Footprint - average per person for all of humanity. & $3.1 \mathrm{ghpc}$ \\
\hline Biocapacity available for human use at $50 \%$ of 2050 value of $1.3 \mathrm{ghpc}-$ average per person for all of humanity. & $0.7 \mathrm{ghpc}$ \\
\hline Ecological-Footprint as a \% of available Biocapacity (i.e., the reduction in 'I' that 'T' needs to achieve). & $466 \%$ \\
\hline
\end{tabular}

Source: Clifton (2010d)

Notes:

\#1: Projected population change to 2050 is based on the United Nations mid-range estimate that will see the human population grow for approximately 6.5 b today to about 9 b by 2050 (UN, 2007).

\#2: Uncertainty exists on the relationship between increases in population ('P') and economic growth ('A'), and changes in Ecological-Footprint ('I'). The 50\% change relationship used here is an optimistic estimate. For a detailed discussion on this issue, see Clifton (2010d).

Figure 4. SAG case study data sources

\begin{tabular}{|c|c|}
\hline \multicolumn{1}{|c|}{ Document type } & Number \\
\hline 1. Internal to the SAG & 123 \\
\hline $\begin{array}{l}\text { (a) SAG reports (planning documents, departmental annual reports and business plans, policy } \\
\text { statements, etc). }\end{array}$ & 8 \\
\hline (b) Reports commissioned by the SAG from external parties or from appointed advisory bodies. & 14 \\
\hline (c) Ministerial media releases. & 44 \\
\hline (d) General (SAG departmental newsletters, on-line updates, web sites, brochures, and flyers). & 16 \\
\hline (e) Enacted legislation and regulations. & 205 \\
\hline Sub total - internal to the SAG. & 23 \\
\hline 2. External to the SAG & 76 \\
\hline (a) Australian Government (reports, legislation, and agreements). & 40 \\
\hline (b) Non-government & 22 \\
\hline (i) Media items (local and national press). & 14 \\
\hline (ii) Reports (academic, NGO, and other reports). & 99 \\
\hline (ii) General (speech transcripts, NGO newsletters and web sites, and other items). & $\mathbf{3 0 4}$ \\
\hline Sub total - external to the SAG. & \\
\hline Grand total - all documents & \\
\hline
\end{tabular}


Figure 5. South Australian Government sustainability terminologies

\section{Terms (with sample document references):}

Sustainability (SAG, 2004d, 2004e, 2004f, 2006i, 2007e, 2007h).

Sustainable development (SA, 1993a; SAG, 2004d, 2005f, 2006b, 2006i, 2007d, 2007e, 2007h, 2007v).

Ecologically sustainable development (AG, 1992a; SA, 1993b, 2001, 2003b, 2004, 2007b, 2008b; SAG, 2003a, 2004a, 2004b, 2004c, 2005a, 2005c, 2006a, 2006e, 2006f, 2006i, 2007d, 2007e, 20071, 2007p, 2007s, 2008c, 2008d, 2008i).

Environmental/ecological sustainability (SAG, 2003a, 2003b, 2004a, 2006c, 2006h, 2006i, 2007d, 2007i, 2007v, 2007w).

Economic sustainability (SAG, 2004e, 2006d, 2006f, 2007m, 2008j).

Social sustainability (SAG, 2004e, 2005g, 2007a, 2007b, 2007i, 2008j).

Sustainability as a 3-element concept of economic, social, and ecological (SAG, 2004e, 2005c, 2006a, 2007p).

Attaining sustainability (SAG, 2005f, 2006h, 2007g, 2007r, 2007u, 2007v).

\section{Specific things to be sustained or conducted in sustainable ways (with sample document references):}

Biodiversity (SAG, 2007p).

Business (SAG, 2004e); Environmentally sustainable business (SAG, 2006d).

Building design(SAG, 2007e); Housing (SAG, 2007i).

Economy (SAG, 2004e); Economic growth (SAG, 2007t); Strong economic growth (SAG, 2007v); Growth (SAG, 2007c, 2008i); Growth of our State (SAG, 2007c); Economic development (SAG, 2003b, 2005d, 2007r, 2008i).

Employment (SAG, 2007j).

Industries; Agriculture (SAG, 2008d); Aquaculture (SAG, 2008i); Defence (SAG, 2008i); Forestry (SAG, 2008i); Manufacturing (SAG, u.d.); Primary and other industries (SAG, 2006i).

Natural resource management (SAG, 2004a); Use of natural resources (SAG, 2003b, 2007v, 2008d); Use of water (SAG, 2007v).

Population growth (SAG, 2004e).

South Australian Government operations (SAG, 2006e).

Society (SAG, 2007s, 2007w); Community(ies) (SAG, 2004e, 2005b, 2008d, 2008i); Adelaide (SAG, 2005e); South Australia (SAG, 2004e, 2006b, u.d.); Prosperity for South Australians (SAG, 2007b); Future for South Australia (SAG, 2007v); Lives ('live sustainably') (SAG, 2007v).

Figure 6. South Australia (SA) - current Footprint-Analysis data

\begin{tabular}{|c|c|}
\hline \multicolumn{1}{|c|}{ Item } & \multicolumn{2}{c|}{ Value } \\
\hline 1. Base Footprint-Analysis data for South Australia (SA) (Agrawal, Boland, \& Filar, u.d.; SAG, 2006g, 2007n, 2007v) \\
\hline Ecological-Footprint - average per person for all SA residents. & $7.0 \mathrm{ghpc}$ \\
\hline Biocapacity - average per person for all SA residents. & $7.5 \mathrm{ghpc}$ \\
\hline Ecological-Footprint as a percentage of Biocapacity. & $93 \%$ \\
\hline 2. SA Footprint-Analysis data after allowing for 50\% of Biocapacity as unavailable for human use \\
\hline SA Biocapacity available for human use - average per person for all SA residents. & 3.8 ghpc \\
\hline Ecological-Footprint as a percentage of Biocapacity. & $186 \%$ \\
\hline
\end{tabular}

Source: Clifton (2010e).

Figure 7. South Australia Government (SAG) year 2050 Ecological-Footprint target

\begin{tabular}{|l|c|}
\hline \multicolumn{1}{|c|}{ Item } & Value \\
\hline SAG 2050 Ecological-Footprint target - per person for all South Australian (SA) residents. & 3.7 ghpc \\
\hline SA's projected Biocapacity in 2050 based on population change only - per person for all SA residents. & 5.7 ghpc \\
\hline SA's projected 2050 Biocapacity allowing 50\% not available for human use - per person for all SA residents. & 2.9 ghpc \\
\hline
\end{tabular}

Source: Clifton (2010e). 